Article

\title{
Antiplasmodial Activity of Nitroaromatic Compounds: Correlation with Their Reduction Potential and Inhibitory Action on Plasmodium falciparum Glutathione Reductase
}

\author{
Audronè Marozienė ${ }^{1}$, Mindaugas Lesanavičius ${ }^{1}$, Elisabeth Davioud-Charvet ${ }^{2}{ }^{(D)}$ \\ Alessandro Aliverti $\left.{ }^{3}{ }^{(}\right)$, Philippe Grellier ${ }^{4}\left(\mathbb{D}\right.$, Jonas Šarlauskas ${ }^{1}\left(\mathbb{D}\right.$ and Narimantas Čènas ${ }^{1, *}$ \\ 1 Department of Xenobiotics Biochemistry, Institute of Biochemistry of Vilnius University, Saulètekio 7, \\ LT-10257 Vilnius, Lithuania; audrone.maroziene@bchi.vu.lt (A.M.); \\ mindaugas.lesanavicius@gmail.com (M.L.); jonas.sarlauskas@bchi.vu.lt (J.Š.) \\ 2 UMR7042 CNRS-Unistra-UHA, Laboratoire d'Innovation Moléculaire et Applications (LIMA), Bioorganic \\ and Medicinal Chemistry Team, European School of Chemistry, Polymers and Materials, 25 rue Becquerel, \\ F-67087 Strasbourg, France; elisabeth.davioud@unistra.fr \\ 3 Department of Biosciences, Universita degli Studi di Milano, via Celoria 26, I-20133 Milano, Italy; \\ alessandro.aliverti@unimi.it \\ 4 MCAM, UMR7245, Museum National d'Histoire Naturelle, CNRS, 61 rue Buffon, \\ F-75231 Paris CEDEX 05, France; philippe.grellier@mnhn.fr \\ * Correspondence: narimantas.cenas@bchi.vu.lt; Tel.: +370-5-223-4392
}

Academic Editor: Thomas J. Schmidt

Received: 25 October 2019; Accepted: 4 December 2019; Published: 10 December 2019

check for updates

\begin{abstract}
With the aim to clarify the mechanism(s) of action of nitroaromatic compounds against the malaria parasite Plasmodium falciparum, we examined the single-electron reduction by P. falciparum ferredoxin:NADP ${ }^{+}$oxidoreductase (PfFNR) of a series of nitrofurans and nitrobenzenes $(n=23)$, and their ability to inhibit $P$. falciparum glutathione reductase ( $P f \mathrm{GR})$. The reactivity of nitroaromatics in $P f$ FNR-catalyzed reactions increased with their single-electron reduction midpoint potential $\left(E^{1}{ }_{7}\right)$. Nitroaromatic compounds acted as non- or uncompetitive inhibitors towards $P f G R$ with respect to $\mathrm{NADPH}$ and glutathione substrates. Using multiparameter regression analysis, we found that the in vitro activity of these compounds against $P$. falciparum strain $\mathrm{FcB} 1$ increased with their $E^{1}{ }_{7}$ values, octanol/water distribution coefficients at $\mathrm{pH} 7.0(\log D)$, and their activity as $P f G R$ inhibitors. Our data demonstrate that both factors, the ease of reductive activation and the inhibition of $P f G R$, are important in the antiplasmodial in vitro activity of nitroaromatics. To the best of our knowledge, this is the first quantitative demonstration of this kind of relationship. No correlation between antiplasmodial activity and ability to inhibit human erythrocyte GR was detected in tested nitroaromatics. Our data suggest that the efficacy of prooxidant antiparasitic agents may be achieved through their combined action, namely inhibition of antioxidant NADPH:disulfide reductases, and the rapid reduction by single-electron transferring dehydrogenases-electrontransferases.
\end{abstract}

Keywords: nitroaromatics; Plasmodium falciparum; ferredoxin:NADP ${ }^{+}$oxidoreductase; glutathione reductase; enzyme inhibition

\section{Introduction}

The emergence of the resistance of the malaria parasite Plasmodium falciparum to available drugs (e.g., chloroquine or artemisinin [1]) has resulted in the demand for new antimalarial agents and in a better understanding of their mechanisms of action. P. falciparum is particularly vulnerable to oxidative 
stress, that is, to enhanced generation of reactive oxygen species (ROS), which may be caused by the absence of the antioxidant enzymes catalase and glutathione peroxidase [2].

The antibacterial and antiparasitic activity of nitroaromatic compounds $\left(\mathrm{ArNO}_{2}\right)$ is well known. In addition to a number of nitroheterocyclic drugs such as nifurtimox and benznidazole that have been used against Chagas disease and sleeping sickness since the 1970s, a new 5-nitroimidazole derivative, fexinidazole, has recently been approved for a treatment against sleeping sickness [3]. Frequently, the therapeutic action of $\mathrm{ArNO}_{2}$ is attributed to single-electron reduction into their anion radicals $\left(\mathrm{ArNO}_{2}{ }^{-}\right)$, which in turn undergo redox cycling with the formation of ROS, or to their two/four-electron reduction into hydroxylamines (ArNHOH), able to modify DNA [4-6]. The single-electron reduction of $\mathrm{ArNO}_{2}$ is commonly performed by flavoenzymes dehydrogenases- electrontransferases, which possess natural single-electron acceptors, such as heme- or FeS-proteins [7-10]. However, there is a relative lack of information about the enzymes responsible for these reactions in parasites. Another point of view is that in trypanosomatids and Leishmania spp., a possible mode of $\mathrm{ArNO}_{2}$ action is the inhibition of the antioxidant flavoenzyme trypanothione reductase (TR) [11-16]. In this case, nitroaromatics also undergo TR-catalyzed redox cycling. In schistosomatids, a possible target of $\mathrm{ArNO}_{2}$ and other aromatic electron-deficient compounds is thioredoxin glutathione reductase $[17,18]$.

A number of nitrofurans, nitrobenzenes, nitroimidazoles, and 4-nitrobenzothiadiazole were shown to possess in vitro antiplasmodial activity at micromolar or lower concentrations [19-23]; however, the mechanisms of their action remain poorly understood. The activity of a series of nitrobenzenes and nitrofurans roughly increased with their single-electron reduction midpoint potential (redox potential of $\mathrm{ArNO}_{2} / \mathrm{ArNO}_{2}{ }^{-}$couple, $E^{1}$ ) [19], thus demonstrating a possible relationship between the compound's ease of reductive activation and antiplasmodial activity. The antimalarial activity of nitrothiophenes was also attributed to the formation of ROS [24]. On the other hand, nitroaromatic compounds inhibit antioxidant flavoenzyme glutathione reductase from various sources $[19,23,25,26]$. Since $P$. falciparum glutathione reductase (PfGR) plays a key role in the antioxidant defense of the parasite $[2,27,28]$, it is believed that its inhibitors may act as efficient antiplasmodial agents. PfGR is a $2 \times 55 \mathrm{kD}$ homodimer containing FAD and catalytic disulfide in each subunit, which catalyzes the reduction of glutathione (GSSG) at the expense of NADPH [29]. Human erythrocyte host glutathione reductase (HGR) possesses $45 \%$ amino acid sequence identity with $P f G R$ and its role in the parasite survival is a matter of debate. Both PfGR and HGR are inhibited by aromatic electron-deficient compounds which were observed to bind at the dimer interface $[27,28]$. Our previous study demonstrated the absence of relationship between the antiplasmodial activity of nitroaromatic compounds and their efficacy as HGR inhibitors [19]. However, the relationship between the PfGR inhibition and the antiplasmodial activity of nitroaromatics has not been studied so far.

Extending our previous studies [19,30], here we demonstrate that the in vitro antiplasmodial activity of nitroaromatic compounds partly correlates with their efficacy as PfGR inhibitors, and partly with their reactivity with single-electron transferring $P$. falciparum ferredoxin:NADP ${ }^{+}$oxidoreductase (PfFNR). Given the data currently available, $P f F N R$ may act as the most efficient generator of $\mathrm{ArNO}_{2}$ free radicals in Plasmodium.

\section{Results}

\subsection{Relationship between Antiplasmodial Activity of Nitroaromatic Compounds and Their Single-Electron Reduction Midpoint Potential}

The toxicity of nitroaromatic compounds against mammalian cells and bacteria often increases with their single-electron reduction midpoint potential (redox potential of $\mathrm{ArNO}_{2} / \mathrm{ArNO}_{2}{ }^{-}$couple, $E^{1}{ }_{7}$ ). The relationship $\Delta \log \mathrm{IC}_{50} / \Delta E^{1} 7 \sim-10 \mathrm{~V}^{-1}$, where $\mathrm{IC}_{50}$ is the compound concentration for $50 \%$ cell survival or, in the case of bacteria or parasites, for $50 \%$ growth inhibition, indicates that the main factor of cytotoxicity is redox cycling and oxidative stress $[4,8,31]$. Indeed, the rates of single-electron reduction of $\mathrm{ArNO}_{2}$ by flavoenzymes dehydrogenases-electrontransferases, such as NADPH:cytochrome P-450 
reductase, ferredoxin:NADP ${ }^{+}$oxidoreductase, and NO-synthase that initiate their redox cycling, increase with $E^{1}$ of oxidants, and are relatively insensitive to their structure [7-10].

In this work, we used a series of nitroaromatic compounds (Figure 1, Table 1) with available $E^{1} 7$ values. For a major part of them, the $\mathrm{IC}_{50}$ values against the chloroquine-resistant $P$. falciparum strain FcB1 and the inhibition efficacy against HGR were characterized in a previous work [19]. Among the examined compounds, the representatives of vinylquinoline-substituted nitrofurans (IIIa-IIIh, Figure 1) possess well-promising diverse properties such as inhibition of trypanothione reductase, that is, the potential trypanocidal activity [12] as well as bactericidal and antitumor in vitro activity [32,33], the latter property gaining increasing interest [34]. Nitrobenzenes, nitrofurantoin, and nifuroxime (compounds 1-9,12,14,23, Table 1) were used as model compounds. Table 1 reports the $\mathrm{IC}_{50}$ values of compounds against $P$. falciparum strain $\mathrm{FcB} 1$, their $E^{1}{ }_{7}$ values, and their calculated octanol/water distribution coefficients $(\log D)$. Importantly, the $\mathrm{IC}_{50}$ values for several nitroaromatic compounds obtained in separate studies were sufficiently close (Table 1). For quantitative analysis, when available, data obtained within the current work were used. The regression analysis of the log $\mathrm{IC}_{50}$ versus $E^{1}{ }_{7}$ relationship yielded a ratio $\Delta \log \mathrm{IC}_{50} / \Delta E^{1}{ }_{7}=-8.37 \pm 1.25 \mathrm{~V}^{-1}\left(r^{2}=0.6802\right)$ (Figure $\mathrm{S} 1$, Supplementary Materials). The dependence of $\log \mathrm{IC}_{50}$ on $\log D$ is poorly expressed $\left(r^{2}=0.2913\right.$, Figure S2 Supplementary Materials). However, an introduction of compound $\log D$ as a second independent variable resulted in some improvement of the correlation:

$$
\log \mathrm{IC}_{50}=-(0.65 \pm 0.44)-(7.39 \pm 1.34) E^{1}{ }_{7}-(0.12 \pm 0.07) \log D_{,}\left(r^{2}=0.7193\right)
$$

I<smiles>CN(c1c([N+](=O)[O-])cc([N+](=O)[O-])cc1[N+](=O)[O-])[N+](=O)[O-]</smiles>

III<smiles>[R]c1cc(/C=C/c2ccc([N+](=O)[O-])o2)nc2ccccc12</smiles>

II<smiles>NC(=O)c1cc(N2CC2)c([N+](=O)[O-])cc1[N+](=O)[O-]</smiles>

R:

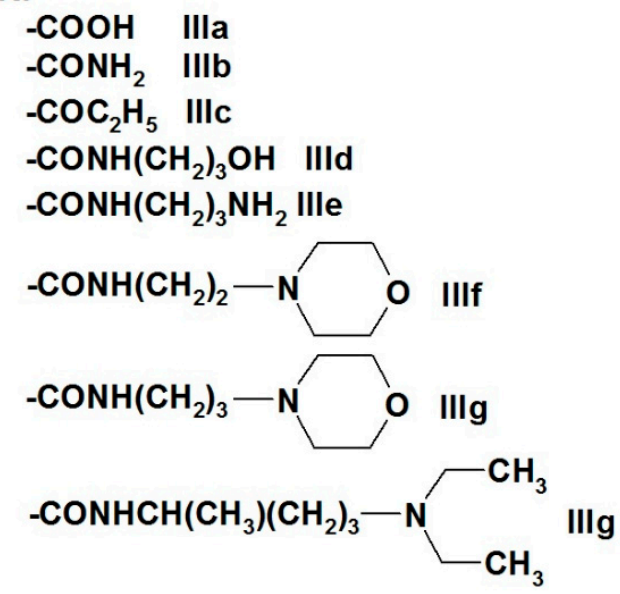

Figure 1. Formulae of nontrivial nitroaromatic compounds studied in this work: I, tetryl; II, CB-1954; and III, vinylquinoline-substituted nitrofurans. 
Table 1. Single-electron reduction midpoint potentials $\left(E^{1}\right)$ of nitroaromatic compounds, their concentrations for $50 \%$ Plasmodium falciparum growth inhibition $\left(\mathrm{IC}_{50}\right)$, their calculated octanol/water distribution coefficients at $\mathrm{pH} 7.0(\log D)$, and their apparent bimolecular reduction rate constants by Plasmodium falciparum ferredoxin:NADP ${ }^{+}$oxidoreductase (PfFNR) $\left(k_{\text {cat }} / K_{\mathrm{m}}\right)$.

\begin{tabular}{|c|c|c|c|c|c|}
\hline No. & Compound & $E_{7}^{1}(\mathrm{~V})[35]$ & $\mathrm{IC}_{50}(\mu \mathrm{M})[19]$ & $\log D$ & $\begin{array}{c}k_{\text {cat }} / K_{\mathrm{m}} \\
\left(\mathrm{M}^{-1} \cdot \mathrm{s}^{-1}\right)\end{array}$ \\
\hline 1 & Nitrobenzene & -0.485 & $473 \pm 113$ & 1.91 & $5.5 \pm 0.8 \times 10^{1}$ \\
\hline 2 & 4-Nitrobenzoic acid & -0.425 & $360 \pm 16 ; 450 \pm 70.7^{b}$ & -1.66 & $4.5 \pm 0.6 \times 10^{2}$ \\
\hline 3 & CB-1954 & -0.380 & $48.5 \pm 5.0^{b}$ & 0.64 & $2.8 \pm 0.3 \times 10^{3}$ \\
\hline 4 & 4-Nitroacetophenone & -0.355 & $172 \pm 8.0$ & 1.47 & $3.3 \pm 0.3 \times 10^{3}$ \\
\hline 5 & 3,5-Dinitrobenzoic acid & -0.350 & $390 \pm 17$ & -1.79 & $3.9 \pm 0.3 \times 10^{3}$ \\
\hline 6 & 1,3-Dinitrobenzene & -0.345 & $50.5 \pm 2.4$ & 1.85 & $2.7 \pm 0.3 \times 10^{3}$ \\
\hline 7 & 4-Nitrobenzaldehyde & -0.325 & $79 \pm 28$ & 1.63 & $4.0 \pm 0.3 \times 10^{3}$ \\
\hline 8 & 3,5-Dinitrobenzamide & -0.311 & $30.3 \pm 3.1 ; 26.5 \pm 6.4^{b}$ & 0.7 & $4.9 \pm 0.4 \times 10^{3}$ \\
\hline 9 & 1,2-Dinitrobenzene & -0.287 & $11.7 \pm 1.1$ & 1.85 & $1.1 \pm 0.2 \times 10^{4}$ \\
\hline 10 & Nitrofurantoin & -0.255 & $12.9 \pm 1.3$ & -0.25 & $6.8 \pm 0.7 \times 10^{4}$ \\
\hline 11 & Nifuroxime & -0.255 & $14.7 \pm 0.8$ & -0.34 & $3.3 \pm 0.4 \times 10^{4}$ \\
\hline 12 & 1,4-Dinitrobenzene & -0.255 & $0.26 \pm 0.03$ & 1.85 & $9.3 \pm 0.8 \times 10^{4}$ \\
\hline 13 & $2,4,6$-Trinitrotoluene & -0.253 & $9.4 \pm 7.8^{b}$ & 2.31 & $1.3 \pm 0.1 \times 10^{4}$ \\
\hline 14 & N-Methylpicramide & -0.247 & $7.3 \pm 1.1^{b}$ & 1.92 & $6.8 \pm 0.5 \times 10^{4}$ \\
\hline 15 & Nitrofuran IIIa & $-0.225^{a}$ & $17.1 \pm 1.5$ & 0.27 & $4.8 \pm 0.5 \times 10^{4}$ \\
\hline 16 & Nitrofuran IIIlb & $-0.225^{a}$ & $4.5 \pm 0.3$ & 2.64 & $1.6 \pm 0.2 \times 10^{5}$ \\
\hline 17 & Nitrofuran IIIc & $-0.225^{a}$ & $7.4 \pm 0.3$ & 2.87 & n.d. \\
\hline 18 & Nitrofuran IIId & $-0.225^{a}$ & $7.4 \pm 0.3$ & 3.23 & n.d. \\
\hline 19 & Nitrofuran IIIe & $-0.225^{a}$ & $9.2 \pm 0.3$ & 2.24 & n.d. \\
\hline 20 & Nitrofuran IIIf & $-0.225^{a}$ & $11.1 \pm 0.4$ & 2.62 & n.d. \\
\hline 21 & Nitrofuran IIIg & $-0.225^{a}$ & $6.4 \pm 0.4$ & 2.45 & $8.3 \pm 0.7 \times 10^{4}$ \\
\hline 22 & Nitrofuran IIIh & $-0.225^{a}$ & $4.3 \pm 0.3$ & 2.62 & n.d. \\
\hline 23 & Tetryl & -0.191 & $4.1 \pm 0.8^{b}$ & 1.38 & $2.0 \pm 0.3 \times 10^{5}$ \\
\hline
\end{tabular}

${ }^{\mathrm{a}}$ The $E^{1}{ }_{7}$ values are taken from [19], ${ }^{\mathrm{b}}$ The values of $\mathrm{IC}_{50}$ determined in this work. n.d., not determined.

This shows that the oxidant potency of nitroaromatics and, to some extent, their lipophilicity play definite roles in their antiplasmodial activity.

\subsection{Single-Electron Reduction of Nitroaromatics by PfFNR and PfGR}

To the best of our knowledge, the pathways of reduction of nitroaromatic compounds in P. falciparum are not yet well understood. Among flavoenzymes dehydrogenases-electrontransferases that can initiate redox cycling of $\mathrm{ArNO}_{2}$, a potential candidate is ferredoxin:NADP ${ }^{+}$oxidoreductase localized in the apicoplast of the parasites [36,37]. This enzyme plays a significant role in parasite survival, because the functional analysis of $P$. falciparum genome revealed a high fitness cost of disruption of its gene [38]. Table 1 lists the bimolecular reduction rate constants of $\mathrm{ArNO}_{2}$ by $\operatorname{PfFNR}\left(k_{\mathrm{cat}} / K_{\mathrm{m}}\right)$. The $k_{\mathrm{cat}}$ values of the reactions were not determined because of a nearly linear dependence of reaction rate on $\mathrm{ArNO}_{2}$ concentration except for the most reactive oxidant tetryl $\left(k_{\mathrm{cat}}=27.5 \pm 2.0 \mathrm{~s}^{-1}\right)$.

Figure 2 shows the linear relationship between $\log k_{\text {cat }} / K_{\mathrm{m}}$ and $E^{1}{ }_{7}$ of nitroaromatics characterized by the ratio $\Delta \log \left(k_{\text {cat }} / K_{\mathrm{m}}\right) / \Delta E^{1}{ }_{7}=11.69 \pm 0.73 \mathrm{~V}^{-1}\left(r^{2}=0.9408\right)$, which mirrors to some extent the relationship between $\log \mathrm{IC}_{50}$ and $E^{1}{ }_{7}$ (Equation (1)). PfFNR catalyzes a single-electron reduction of $\mathrm{ArNO}_{2}$, as demonstrated by the observation that in the presence of compounds 5,12,14, and 23 (Table 1), the reduction of added cytochrome $c$ takes place at rates that are 140-195\% those of NADPH oxidation. Moreover, the reduction of cytochrome $c$ is $15-25 \%$ inhibited by $100 \mathrm{U} / \mathrm{mL}$ superoxide dismutase. The redox cycling of $\mathrm{ArNO}_{2}$ is also evident from the consumption of excess $\mathrm{O}_{2}$ over $\mathrm{ArNO}_{2}$ during the reaction (Figure 3A). However, it is also important to note that $P f$ FNR-catalyzed formation of stable products of $\mathrm{ArNO}_{2}$ reduction does not start after complete $\mathrm{O}_{2}$ exhaustion, but takes place at 
$\left[\mathrm{O}_{2}\right]=40-50 \mu \mathrm{M}$ after an initial lag time (in the case of $N$-methylpicramide or nitrofurantoin), or starts even without delay (in the case of tetryl or $p$-dinitrobenzene) (Figure 3B).

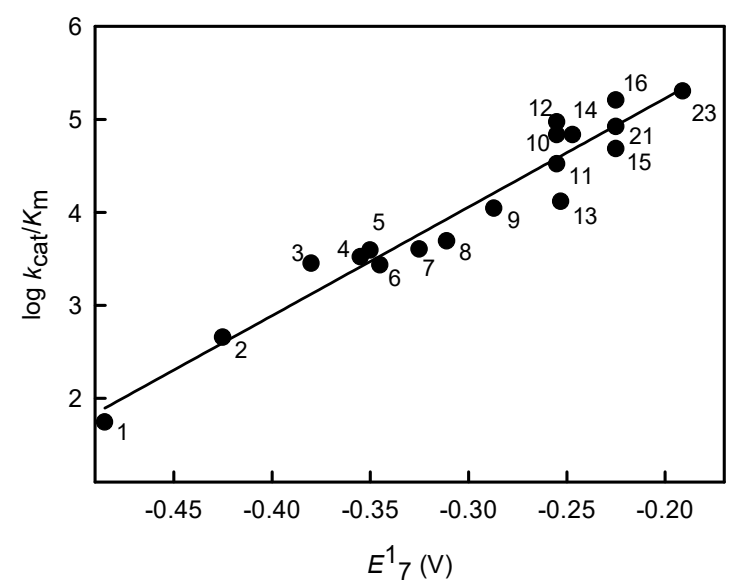

Figure 2. Relationship between the reactivity of nitroaromatic compounds in $P f F N R$-catalyzed reactions $\left(\log k_{\text {cat }} / K_{\mathrm{m}}\right)$ and their single-electron reduction midpoint potentials $\left(E^{1}{ }_{7}\right)$. The numbers of compounds correspond to those in Table 1.

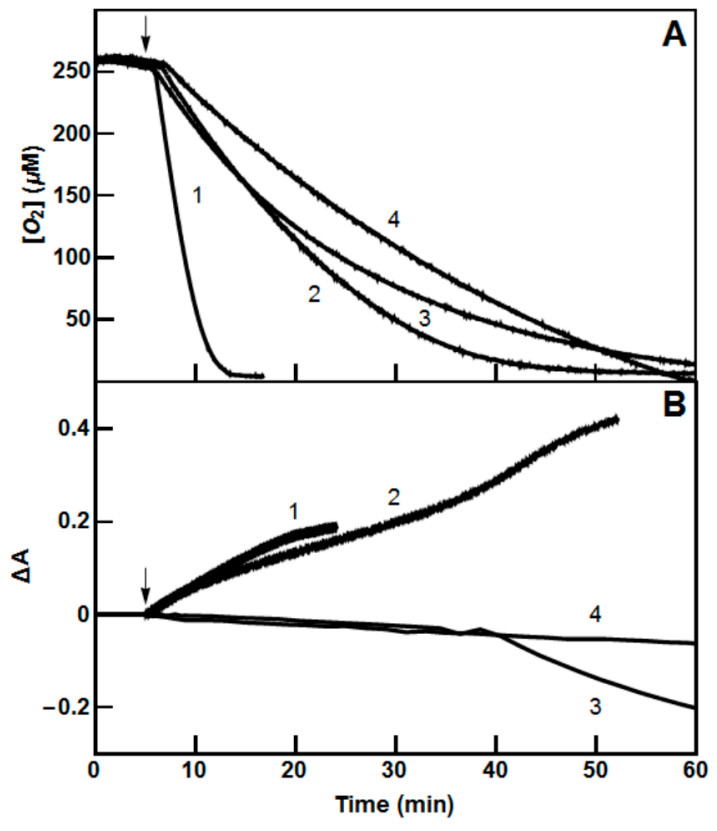

Figure 3. (A) Time course of oxygen consumption and (B) spectral changes during reduction of tetryl (trace 1), 1,4-dinitrobenzene (trace 2), nitrofurantoin (trace 3), and $N$-methylpicramide (trace 4 ) by $50 \mathrm{nM}$ PfFNR and NADPH-regeneration system under the absence of external oxygen supply. Compound concentration, $50 \mu \mathrm{M}$, absorbance monitored at $420 \mathrm{~nm}$ (tetryl), $340 \mathrm{~nm}$ (1,4-dinitrobenzene), $420 \mathrm{~nm}$ (nitrofurantoin), and $343 \mathrm{~nm}$ ( $\mathrm{N}$-methylpicramide). The arrows indicate the time of introduction of PfFNR.

Both yeast and erythrocyte GR catalyze the single-electron reduction of nitroaromatics, although at a low rate $[19,25]$. Since the formed $\mathrm{ArNO}_{2}{ }^{-}$undergoes further redox cycling, nitroaromatics are considered as "subversive substrates" for GR. Moreover, there is some evidence that redox-active xenobiotics may be reduced at the $\operatorname{NADP}(\mathrm{H})$ binding site of GR $[39,40]$. It is supposed that the same reactions catalyzed by trypanothione reductase are at least partly responsible for the trypanocidal activity of nitrofurans [11]. Among the examined compounds, tetryl oxidized PfGR most efficiently $\left(k_{\text {cat }}\right.$ $=5.9 \pm 0.5 \mathrm{~s}^{-1}$ and $k_{\text {cat }} / K_{\mathrm{m}}=7.6 \pm 0.8 \times 10^{3} \mathrm{M}^{-1} \cdot \mathrm{s}^{-1}$ ), with parameters similar to those of HGR oxidation 
$\left(k_{\text {cat }} \geq 5.0 \mathrm{~s}^{-1}, k_{\text {cat }} / K_{\mathrm{m}}=2.0 \times 10^{3} \mathrm{M}^{-1} \cdot \mathrm{s}^{-1}\right.$ [37]). When present, cytochrome $c$ was reduced at rates that are $170-180 \%$ those of NADPH oxidation, through a process partly inhibited by superoxide dismutase. 2,4,6-Trinitrotoluene (TNT) $\left(k_{\text {cat }}=0.2 \pm 0.05 \mathrm{~s}^{-1}, k_{\text {cat }} / K_{\mathrm{m}}=150 \pm 40 \mathrm{M}^{-1} \cdot \mathrm{s}^{-1}\right), 1,4$-dinitrobenzene $\left(k_{\text {cat }}\right.$ $\left.=0.3 \pm 0.07 \mathrm{~s}^{-1}, k_{\text {cat }} / K_{\mathrm{m}}=300 \pm 60 \mathrm{M}^{-1} \cdot \mathrm{s}^{-1}\right)$, and nifuroxime $\left(k_{\text {cat }} \leq 0.06 \mathrm{~s}^{-1}, k_{\text {cat }} / K_{\mathrm{m}} \leq 110 \mathrm{M}^{-1} \cdot \mathrm{s}^{-1}\right)$ oxidized PfGR much more slowly. Other nitroaromatic compounds were even less efficient oxidants of PfGR. At their saturating concentrations, the rate of NADPH oxidation was almost indistinguishable from the intrinsic NADPH-oxidase activity of the enzyme, $0.07 \mathrm{~s}^{-1}$. This is in line with the previously reported properties of yeast and erythrocyte GR [19,25]. In conclusion, PfGR-catalyzed redox cycling of nitroaromatics proceeds with much lower rates than in the analogous reaction of $P f F N R$.

\subsection{Inhibition of P. falciparum Glutathione Reductase by Nitroaromatic Compounds}

Next, we analyzed the inhibition of P. falciparum GR by $\mathrm{ArNO}_{2}$. PfGR acts through a "ping-pong" reaction mechanism with separate reductive and oxidative half-reactions [29]. At saturating concentrations of substrates, $100 \mu \mathrm{M}$ NADPH and $1.0 \mathrm{mM}$ GSSG, the catalytic constant $\left(\boldsymbol{k}_{\text {cat }}\right)$ of $P f G R$ was $138 \pm 4.0 \mathrm{~s}^{-1}$. Nitroaromatic compounds acted on PfGR as non- or uncompetitive inhibitors with respect to GSSG at fixed NADPH concentration (Figure 4A,B). Similarly, nitroaromatics acted as uncompetitive inhibitors with respect to NADPH at fixed GSSG concentration (Figure 5).

These findings are in line with the well-characterized inhibition of yeast and human erythrocyte GR by nitroaromatics $[19,25]$, and PfGR and HGR by arylisoalloxazines and quinones $[27,30,41]$. The latter compounds may bind at the interface domain of two subunits of PfGR in the vicinity of Val-56,56' and Asp-58,58', which correspond to His-75,75' and Phe-78,78' in HGR [27]. This site is distant from both the NADP $(\mathrm{H})$ - and GSSG-binding regions. The $K_{\mathrm{i}}$ values of nitroaromatic compounds of $P f G R$ determined using GSSG as a variable substrate (Figure 4A,B), are given in Table 2. The table also contains $K_{\mathrm{i}}$ values of nitroaromatic compounds towards HGR determined previously [19] and partly within the present work. Importantly, the $K_{i}$ values for several nitroaromatic compounds obtained in both studies were sufficiently close (Table 2). It should be noted that significant differences exist between HGR and PfGR inhibition constants, and that their log values are poorly related $\left(r^{2}=0.3840\right)$. This may be attributed to differences in the structure, shape, and flexibility of the intersubunit regions of PfGR and HGR [24,25]. However, the analysis of the inhibition profile of the two enzymes is beyond the scope of the present work.
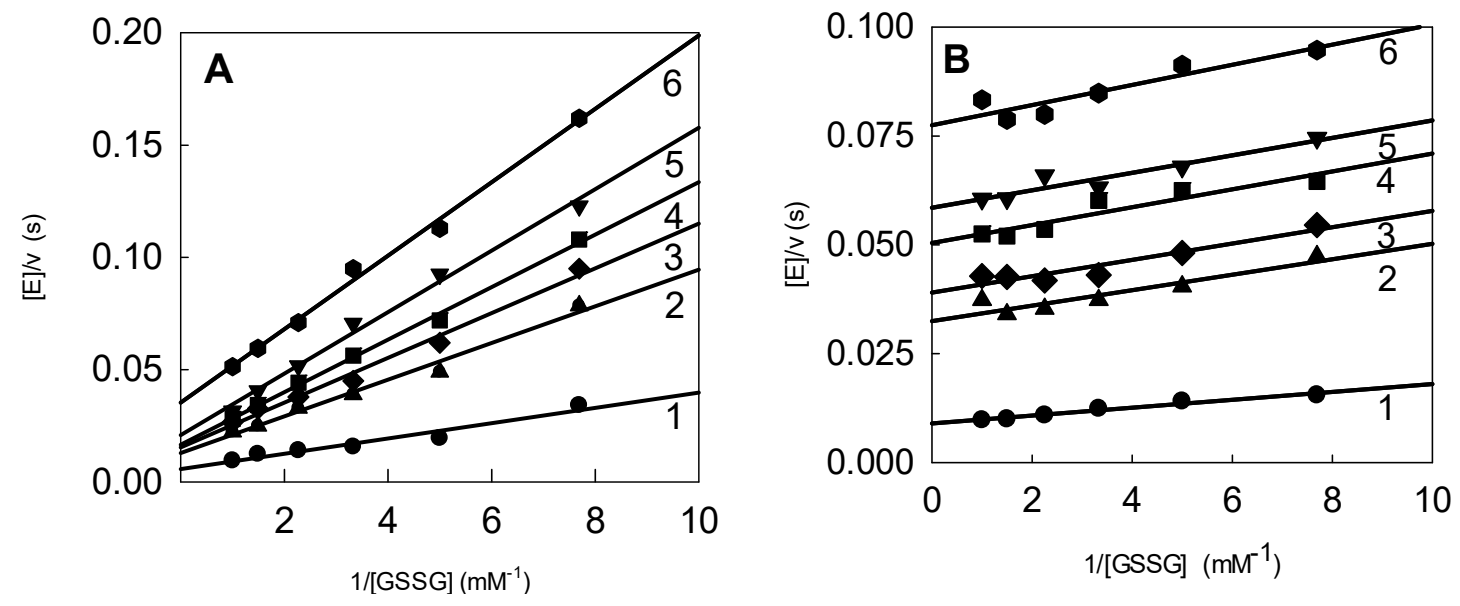

Figure 4. (A) Inhibition of P. falciparum glutathione reductase (PfGR) by nitrofuran IIIa and by TNT (B) at fixed NADPH concentration, $100 \mu \mathrm{M}$, and varied concentrations of GSSG. (A) Concentrations of nitrofuran IIIa: $0.0 \mu \mathrm{M}$ (line 1), $6.7 \mu \mathrm{M}$ (line 2), $10.0 \mu \mathrm{M}$ (line 3), $15.0 \mu \mathrm{M}$ (line 4), $22.2 \mu \mathrm{M}$ (line 5), and $50 \mu \mathrm{M}$ (line 6). (B) Concentrations of TNT: $0.0 \mu \mathrm{M}$ (line 1), $13.2 \mu \mathrm{M}$ (line 2), $19.7 \mu \mathrm{M}$ (line 3), $29.6 \mu \mathrm{M}$ (line 4), $44.4 \mu \mathrm{M}$ (line 5), and $100 \mu \mathrm{M}$ (line 6). 


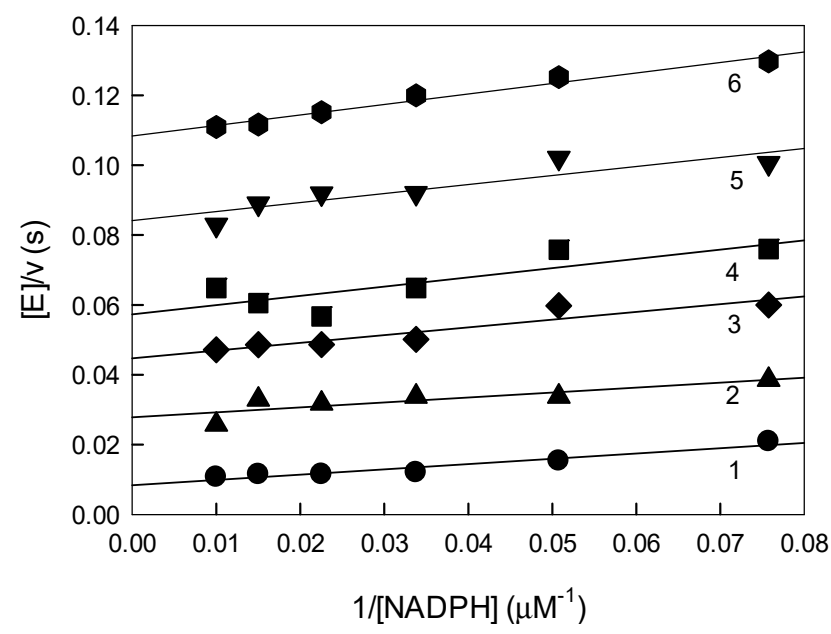

Figure 5. Inhibition of PfGR by nitrofuran IIIa at fixed GSSG concentration, $1.0 \mathrm{mM}$, and varied concentrations of NADPH. Concentrations of inhibitor: $0.0 \mu \mathrm{M}$ (line 1), $10.0 \mu \mathrm{M}$ (line 2), $20.0 \mu \mathrm{M}$ (line 3), $30.0 \mu \mathrm{M}$ (line 4), $45.0 \mu \mathrm{M}$ (line 5), and $66.7 \mu \mathrm{M}$ (line 6).

Table 2. Inhibition constants of nitroaromatic compounds acting on P. falciparum and human erythrocyte glutathione reductases (HGRs), calculated under constant concentration of NADPH $(100 \mu \mathrm{M})$ and varied concentration of GSSG.

\begin{tabular}{|c|c|c|c|}
\hline \multirow{2}{*}{ No. } & \multirow{2}{*}{ Compound } & \multicolumn{2}{|c|}{$K_{\mathrm{i}}(\mu \mathrm{M})$} \\
\hline & & PfGR ${ }^{a}$ & HGR $^{b}$ \\
\hline 1 & Nitrobenzene & $\geq 6000$ & $\geq 2000$ \\
\hline 2 & 4-Nitrobenzoic acid & $1200 \pm 180$ & 800 \\
\hline 3 & CB-1954 & $350 \pm 40$ & $\geq 1000$ \\
\hline 4 & 4-Nitroacetophenone & $70 \pm 11$ & 400 \\
\hline 5 & 3,5-Dinitrobenzoic acid & $220 \pm 29$ & 350 \\
\hline 6 & 1,3-Dinitrobenzene & $40 \pm 5.0$ & $320 ; 350 \pm 30^{a}$ \\
\hline 7 & 4-Nitrobenzaldehyde & $25 \pm 4.0$ & 290 \\
\hline 8 & 3,5-Dinitrobenzamide & $75 \pm 9.0$ & $\geq 1000$ \\
\hline 9 & 1,2-Dinitrobenzene & $30 \pm 4.0$ & $\geq 1000$ \\
\hline 10 & Nitrofurantoin & $9.0 \pm 1.0$ & 200 \\
\hline 11 & Nifuroxime & $32 \pm 5.0$ & 200 \\
\hline 12 & 1,4-Dinitrobenzene & $0.85 \pm 0.13$ & 71 \\
\hline 13 & 2,4,6-Trinitrotoluene & $8.0 \pm 2.0$ & $6.0^{c} ; 5.2 \pm 0.6^{a}$ \\
\hline 14 & N-Methylpicramide & $5.9 \pm 0.6$ & $10^{\mathrm{c}}$ \\
\hline 15 & Nitrofuran IIIa & $9.0 \pm 1.0$ & $3.0 ; 3.5 \pm 0.2^{\mathrm{a}}$ \\
\hline 16 & Nitrofuran IIIb & $25 \pm 3.0$ & 2.5 \\
\hline 17 & Nitrofuran IIIc & $115 \pm 17$ & 25 \\
\hline 18 & Nitrofuran IIId & $50 \pm 6.0$ & $\geq 300$ \\
\hline 19 & Nitrofuran IIIe & $5.0 \pm 1.0$ & 2.5 \\
\hline 20 & Nitrofuran IIIf & $75 \pm 10$ & 42.5 \\
\hline 21 & Nitrofuran IIIg & $35 \pm 5.0$ & 25 \\
\hline 22 & Nitrofuran IIIh & $100 \pm 12$ & 45 \\
\hline 23 & Tetryl & $2.3 \pm 0.5$ & $14^{\mathrm{c}}$ \\
\hline
\end{tabular}

The analysis of antiplasmodial activity of nitroaromatics (Tables 1 and 2) shows that the dependence of $\log \mathrm{IC}_{50}$ on $\log K_{\mathrm{i}}$ is poorly expressed in the case of $P f \mathrm{GR}$, being characterized by $r^{2}=0.5878$ (Figure S3, Supplementary Materials). An introduction of $\log D$ as a second variable improved the correlation:

$$
\log \mathrm{IC}_{50}=(0.59 \pm 0.23)+(0.61 \pm 0.11) \log K_{\mathrm{i}}-(0.21 \pm 0.07) \log D,\left(r^{2}=0.7253\right)
$$


Although the $\log \mathrm{IC}_{50}$ of nitroaromatics also increased with their $\log K_{\mathrm{i}}$ for HGR (Table 2), this dependence was poorly expressed $\left(r^{2}=0.3323\right)$. An introduction of $\log D$ as a second variable improved it up to $r^{2}=0.4543$. Finally, the antiplasmodial activity of nitroaromatics was best described by a regression using $E^{1} 7, \log K_{\mathrm{i}}$ for $P f \mathrm{GR}$, and $\log D$ as independent variables:

$$
\log \mathrm{IC}_{50}=-(0.27 \pm 0.43)-(4.16 \pm 1.78) E^{1} 7+(0.36 \pm 0.14) \log K_{\mathrm{i}}-(0.15 \pm 0.07) \log D,\left(r^{2}=0.7866\right)
$$

On the other hand, the use of $\log K_{\mathrm{i}}$ for HGR as a variable resulted in a lower regression coefficient, and in an uncertain relationship between $\log \mathrm{IC}_{50}$ and $\log K_{\mathrm{i}}$ :

$$
\log \mathrm{IC}_{50}=-(0.70 \pm 0.46)-(8.24 \pm 1.90) E^{1}{ }_{7}-(0.10 \pm 0.15) \log K_{\mathrm{i}}-(0.13 \pm 0.08) \log D,\left(r^{2}=0.7252\right)
$$

\section{Discussion}

Our study resolves the debated problem about the mechanisms of antiplasmodial activity of nitroaromatics $[19,23,26]$, and demonstrates that their activity increases both with the ease of their bioreductive activation, expressed as the value of $E^{1}$, and the efficiency of inhibition of $P f G R$ (Equation (3)). These data complement our previous findings on the role of inhibition of PfGR in the activity of quinones against the same strain [30]. In both cases, the relationship between the activity of compounds and their efficiency as $P f G R$ inhibitors is revealed using multiparameter regression analysis. On the analogy with Equation (3), the activity of quinones was described by the relationships with $\Delta \log \mathrm{IC}_{50} / \Delta \log K_{\mathrm{i}}=0.633-0.763$ [30]. These observations point to the importance of $P f \mathrm{GR}$ as potential target for antiplasmodial agents. Apart from protection against the oxidative stress, $P f G R$ supplies GSH for the glyoxalase system, for the degradation of uncrystallized ferriprotoporphyrin IX, and as a source of reducing equivalents for ribonucleotide synthesis and thioredoxin-dependent antioxidant system [43-46]. Although no PfGR knockout data are available in the case of P. falciparum, the functional analysis of its genome revealed a high fitness cost of disruption of the PfGR gene [38]. On the other hand, the comparison between Equations (3) and (4) points to an insignificant role of HGR inhibition in the antiplasmodial action of nitroaromatics. Although the role of HGR in the survival of P. falciparum is a matter of debate [2,47], our data are in favor of its minor importance for parasite killing. However, this does not discard its role in the protection against an oxidative environment which limits the parasite infection rate, as it is in the case of glucose-6-phospate dehydrogenase deficiency [40]. In this context, one may note that the relationship $\Delta \log \mathrm{IC}_{50} / \Delta \log K_{\mathrm{i}}$ (Equation (3)) is significantly lower than unity. It may point to a limited role of inhibition of $P f G R$ in the antiplasmodial activity of nitroaromatics. On the other hand, the disturbance of GSSG/GSH homeostasis under the oxidative or alkylative stress in certain cases may enhance the expression of GR as a compensation mechanism. This phenomenon has been observed in yeast, plants, and mammalian cells [48-51].

In this context, two other issues related to the mechanism of antiplasmodial activity of $\mathrm{ArNO}_{2}$ may be discussed. First is the dependence of their $\mathrm{IC}_{50}$ values on their $E^{1}{ }_{7}$ (Equation (1)), the latter being associated with their redox cycling activity. However, because $P$. falciparum, during its intraerythrocyte stage, adopts microaerophilic metabolism and relies mainly on anaerobic processes [52,53], the role of the ROS-promoted parasite death should be interpreted with caution. On the other hand, Equation (1) may equally well reflect the rates of formation of DNA-damaging hydroxylamines under the action of single-electron transferring enzymes such as PfFNR (Figure 3A,B) which may take place under partly anaerobic conditions. Another point is the role of $P f F N R$ in the formation of free radicals and/or other reduced forms of $\mathrm{ArNO}_{2}$ in plasmodia. To the best of our knowledge, nitroreductase activity of P. falciparum flavoenzymes has not been previously evaluated. Some conclusions may be drawn from the enzyme reactivity with a model compound menadione (2-methyl-1,4-naphthoquinone, $E^{1}{ }_{7}=-0.20 \mathrm{~V}$ ) (Table 3), because, as a rule, flavoenzymes reduce quinones much faster than nitroaromatics, or, in exceptional cases, with similar rates ([7,53], and references therein). Thus, given the data currently available (Table 3), PfFNR may act as the most efficient generator of $\mathrm{ArNO}_{2}$ free radicals in plasmodia. P. falciparum thioredoxin reductase may be next to it according to menadione reductase activity (Table 3 ). 
On the other hand, the nitroreductase activity of mitochondrial type II NADH dehydrogenase is expected to be very low because menadione is slowly reducible. To the best of our knowledge, nitroaromatic compounds and soluble quinones have not been previously studied as oxidants of other enzymes of the mitochondrial respiratory chain, namely dihydroorotate dehydrogenase, succinate dehydrogenase, and malate:quinone oxidoreductase.

Table 3. Kinetic characterization of nitro- and quinone reductase reactions of Plasmodium falciparum flavoenzymes.

\begin{tabular}{|c|c|c|}
\hline \multirow{2}{*}{ Enzyme } & \multicolumn{2}{|c|}{ Oxidants } \\
\hline & $\begin{array}{l}\text { Nitrofurans, Nitrobenzenes } \\
\qquad E^{1}{ }_{7}=-0.25-0.19 \mathrm{~V}\end{array}$ & Menadione \\
\hline$P f \mathrm{FNR}$ & $\begin{array}{c}k_{\text {cat }}>20 \mathrm{~s}^{-1}, k_{\text {cat }} / K_{\mathrm{m}}=4.8 \times 10^{4}- \\
1.6 \times 10^{5} \mathrm{M}^{-1} \cdot \mathrm{s}^{-1}, \text { this work }\end{array}$ & $\begin{array}{c}k_{\text {cat }}=14 \mathrm{~s}^{-1}, k_{\mathrm{cat}} / K_{\mathrm{m}}=1.0 \times 10^{6} \\
\mathrm{M}^{-1} \cdot \mathrm{s}^{-1}[30]\end{array}$ \\
\hline PfGR & $\begin{array}{c}k_{\text {cat }}=0.06-5.9 \mathrm{~s}^{-1}, k_{\text {cat }} / K_{\mathrm{m}}=7.6 \times 10^{3}- \\
110 \mathrm{M}^{-1} \cdot \mathrm{s}^{-1}, \text { this work }\end{array}$ & $\begin{array}{c}k_{\text {cat }}=0.16 \mathrm{~s}^{-1}, k_{\text {cat }} / K_{\mathrm{m}}=2.0 \times 10^{3} \\
\mathrm{M}^{-1} \cdot \mathrm{s}^{-1}[54]\end{array}$ \\
\hline $\begin{array}{l}\text { P. falciparum thioredoxin } \\
\text { reductase }\end{array}$ & & $\begin{array}{c}k_{\text {cat }}=31 \mathrm{~s}^{-1}, k_{\text {cat }} / K_{\mathrm{m}}=1.6 \times 10^{5} \\
\mathrm{M}^{-1} \cdot \mathrm{s}^{-1}[54]\end{array}$ \\
\hline $\begin{array}{l}\text { P. falciparum type II NADH } \\
\text { dehydrogenase }\end{array}$ & & $k_{\mathrm{cat}}=0.1 \mathrm{~s}^{-1}[55]$ \\
\hline
\end{tabular}

A more general conclusion following from our study is that the efficacy of redox active antiparasitic agents such as quinones, nitroaromatic compounds, isoalloxazines, and aromatic $N$-oxides [6] may be achieved through two separate types of action, namely inhibition of antioxidant NADPH:disulfide reductases and rapid reduction by flavoenzymes dehydrogenaseselectrontransferases. Currently, these groups of compounds are mainly considered as "subversive substrates" of disulfide reductases such as glutathione reductase, trypanothione reductase, or thioredoxin reductase [11,30,40,54,56]. However, the single-electron reduction of the above compounds by dehydrogenases-electrontransferases of different origin (e.g., mammalian NADPH: cytochrome P-450 reductase, NO-synthase, NADH:ubiquinone reductase, algal FNR, and bacterial flavohemoglobin) is usually faster [7-10]. Thus, more attention should be given to the studies of these reactions catalyzed by parasite enzymes of this group.

\section{Materials and Methods}

\subsection{Materials}

Recombinant PfGR and P. falciparum ferredoxin:NADP ${ }^{+}$oxidoreductase were prepared as previously described $[29,36]$, and their concentrations were determined spectrophotometrically according to $\varepsilon_{461}=11.7 \mathrm{mM}^{-1} \cdot \mathrm{cm}^{-1}$ and $\varepsilon_{461}=10.1 \mathrm{mM}^{-1} \mathrm{~cm}^{-1}$, respectively. Recombinant HGR was obtained from Sigma-Aldrich (St. Louis, MO, USA), and its concentration was determined according to $\varepsilon_{464}=11 \mathrm{mM}^{-1} \cdot \mathrm{cm}^{-1}$.

Nitrobenzene derivatives 1,2,4-9,12 and nitrofurans 10,11 (Table 1) were obtained from Sigma-Aldrich (St. Louis, MO, USA) and used as received. TNT, 2,4,6-trinitrophenyl-Nmethylnitramine (tetryl) (Figure 1), and N-methylpicramide were synthesized as described in $[57,58]$. 5-(Aziridin-1-yl)-2,4- dinitrobenzamide (CB-1954, Figure 1), synthesized as described in [59], was a generous gift of Dr. Vanda Miškinienė (Institute of Biochemistry, Vilnius, Lithuania). Vinylquinoline-substituted nitrofurans IIIa-h (Figure 1) were synthesized as described in [60,61]. All synthesized compounds were previously verified by determining their melting point, as well as their ${ }^{1} \mathrm{H}-\mathrm{NMR}, \mathrm{UV}$, and IR spectra $[8,19,25]$. The purity of compounds, determined using a high-performance liquid chromatography system equipped with a mass spectrometer (LCMS-2020, Shimadzu, Kyoto, Japan), was $>98 \%$. Cytochrome $c$, NADPH, GSSG, glucose-6-phosphate, glucose-6-phospate 
dehydrogenase, superoxide dismutase, and other compounds were obtained from Sigma-Aldrich (St. Louis, MO, USA) and used as received.

\subsection{Methods}

\subsubsection{Enzyme Kinetic Studies}

All kinetic experiments were carried out spectrophotometrically using a PerkinElmer Lambda 25 UV-VIS spectrophotometer (PerkinElmer, Waltham, MA, USA) in 0.1 M K-phosphate buffer (pH 7.0) containing $1 \mathrm{mM}$ EDTA at $25^{\circ} \mathrm{C}$. The steady-state parameters of reactions, the catalytic constants $\left(k_{\text {cat(app.) }}\right)$, and the bimolecular rate constants (or catalytic efficiency constants, $k_{\text {cat }} / K_{\mathrm{m}}$ ) of the oxidants at fixed concentrations of NADPH correspond to the reciprocal intercepts and slopes of Lineweaver-Burk plots, [E]/v vs. $1 /[$ oxidant], where $v$ is the reaction rate, and [E] is the enzyme concentration. $k_{\text {cat }}$ represents the number of molecules of NADPH oxidized by a single active center of the enzyme per second. The rates of $P f$ FNR- and $P f G R$-catalyzed NADPH oxidation in the presence of nitroaromatic compounds or GSSG were determined using the value $\Delta \varepsilon_{340}=6.2 \mathrm{mM}^{-1} \cdot \mathrm{cm}^{-1}$. The rates were corrected for the intrinsic NADPH-oxidase activity of enzymes, which were equal to $0.12 \mathrm{~s}^{-1}$ and $0.07 \mathrm{~s}^{-1}$ for $P f F N R$ and $P f G R$, respectively. In separate experiments, in which $50 \mu \mathrm{M}$ cytochrome $c$ were included in the reaction mixture, its nitroaromatic-mediated reduction was measured using the value $\Delta \varepsilon_{550}=20 \mathrm{mM}^{-1} \cdot \mathrm{cm}^{-1}$. The kinetic parameters were obtained by the fitting of kinetic data to the parabolic expression using SigmaPlot 2000 version 11.0 (https://systatsoftware.com). The rates of reduction of nitroaromatic compounds $(50 \mu \mathrm{M})$ by PfFNR in the absence of external oxygen supply were monitored in the presence of an NADPH-regeneration system (50 $\mu \mathrm{M}$ NADPH, $10 \mathrm{mM}$ glucose-6-phosphate, and $50 \mathrm{U} / \mathrm{mL}$ yeast glucose-6-phosphate dehydrogenase) at the specific $\lambda_{\max }$ of absorbance of compounds. In these cases, a sealed spectrophotometer cell was completely filled by the solution containing nitroaromatic compound and NADPH-regeneration system, and the reaction was initiated by the injection of $P f$ FNR. In parallel, the rate of oxygen consumption was monitored under identical conditions using a Digital Model 10 Clark electrode (Rank Brothers Ltd., Bottisham, UK). In reversible inhibition studies of PfGR, reaction rates were determined either at fixed NADPH concentration $(100 \mu \mathrm{M})$ and varied GSSG concentrations $(1.0-0.13 \mathrm{mM})$, or at fixed GSSG concentration $(1.0 \mathrm{mM})$ and varied NADPH concentrations $(8-50 \mu \mathrm{M})$, and either in the absence or presence of the inhibitor at 4-6 different concentrations. Using tetryl as inhibitor, the reaction rates were corrected for PfGR- catalyzed NADPH oxidation by tetryl, which was typically less than $0.4 \%$ of total reaction rate. Since CB-1954 possessed significant absorbance at $340 \mathrm{~nm}$, the reaction rate of PfGR was monitored according to GSH-mediated reduction of 5.5'-dithiobis-(2-nitrobenzoic acid) (1.0 mM) using the value $\Delta \varepsilon_{412}=27.2 \mathrm{mM}^{-1} \cdot \mathrm{cm}^{-1}$. The inhibition constants $\left(K_{\mathrm{i}}\right)$ were obtained from the Cleland plots, that is, the dependence of $1 / k_{\text {cat }}$ on the inhibitor concentration ([I]).

\subsubsection{Antiplasmodial In Vitro Activity Studies}

The chloroquine-resistant $P$. falciparum strain FcB1 from Colombia, which is deposited in the Protist collection of Museum National d'Histoire Naturelle, Paris, France, was kindly provided by Dr. H.D. Heidrich (Max-Planck Institut für Biochemie, Martinsried bei München, Germany). P. falciparum FcB1 strain was maintained in continuous culture of human erythrocytes according to [62]. In vitro antiplasmodial activity was determined using a modification of the semiautomatic microdilution technique [63]. Stock solutions of test compounds in DMSO were serially diluted with culture medium and added to asynchronous parasite cultures (1\% parasite infected cells and $1 \%$ final hematocrit) for $24 \mathrm{~h}$, at $37^{\circ} \mathrm{C}$, prior to the addition of $1.825 \mathrm{MBq}$ of $\left[{ }^{3} \mathrm{H}\right.$ ]-hypoxanthine $(0.37-1.11 \mathrm{TBq} / \mathrm{mmol})$, for $24 \mathrm{~h}$. The growth inhibition for each compound concentration was determined according to the radioactivity incorporation into the treated culture as compared with that in the control culture. The experiments were repeated in triplicate. 


\subsubsection{Statistical Analysis and Calculations}

The octanol/water distribution coefficients at $\mathrm{pH} 7.0(\log D)$ of compounds were calculated using LogD Predictor (https://chemaxon.com). The multiparameter regression analysis was performed using Statistica (version 4.3, StatSoft, Toronto, ON, Canada).

Supplementary Materials: The following are available online. Figure S1: Dependence of activity of nitroaromatic compounds against $P$. falciparum $\mathrm{FcB1}\left(\mathrm{IC}_{50}\right)$ on the values of their single-electron reduction midpoint potential $\left(E^{1}{ }_{7}\right)$, Figure S2: Dependence of activity of nitroaromatic compounds against $P$. falciparum $\mathrm{FcB}_{\mathrm{c}}\left(\mathrm{IC}_{50}\right)$ on the values of their $\log D$, Figure S3: Dependence of activity of nitroaromatic compounds against $P$. falciparum $\mathrm{FcB}_{\mathrm{B}}\left(\mathrm{IC}_{50}\right)$ on the values of their inhibition constant $\left(K_{\mathrm{i}}\right)$ of $P$. falciparum glutathione reductase.

Author Contributions: A.M. and M.L. performed kinetic experiments, E.D.-C. and A.A. purified enzymes, P.G. performed antiplasmodial activity studies, J.Š. synthesized compounds, N.Č. designed and supervised the experiments and wrote the manuscript.

Funding: This work was supported by the European Social Fund (Measure No. 09.33-LMT-K-712, Grant No. DOTSUT-34/09.3.3.-LMT-K712-01-0058/LSS-600000-58) (A.M., M.L., J.Š., N.Č.), and by a grant from the Laboratoire d'Excellence ParaFrap (LabEx ParaFrap ANR-11-LABX-0024) and the ANR-PRC program (grant under the PlasmoPrim project) (E.D.-C.). J.Š. and E.D.C. (MC members) thank the COST Action CM1307, entitled "Targeted Chemotherapy towards Diseases caused by Endoparasites" for covering the exchanges and the costs to publish the Special Issue of Molecules "COST Action CM1307-Proceedings in Medicinal and Natural Product Chemistry".

Acknowledgments: We thank Justinas Radvila for excellent technical assistance.

Conflicts of Interest: The authors declare no conflict of interest. The funders had no role in the design of the study; in the collection, analyses, or interpretation of data; in the writing of the manuscript; or in the decision to publish the results.

\section{Abbreviations}

\begin{tabular}{|c|c|}
\hline $\mathrm{ArNO}_{2}$ & Nitroaromatic compound \\
\hline$E^{1} 7$ & $\begin{array}{l}\text { Single-electron reduction midpoint potential of nitroaromatic compound (redox potential } \\
\text { of } \mathrm{ArNO}_{2} / \mathrm{ArNO}_{2}^{-\cdot} \text { couple) at } \mathrm{pH} 7.0\end{array}$ \\
\hline HGR & Human erythrocyte glutathione reductase \\
\hline $\mathrm{IC}_{50}$ & Compound concentration causing $50 \%$ parasite growth inhibition \\
\hline$k_{\text {cat }}$ & Enzyme catalytic constant \\
\hline$k_{\text {cat }} / K_{\mathrm{m}}$ & Enzyme bimolecular rate constant (catalytic efficiency) \\
\hline$K_{\mathrm{i}}$ & Enzyme inhibition constant \\
\hline $\log D$ & Octanol/water distribution coefficient at $\mathrm{pH} 7.0$ \\
\hline PfFNR & P. falciparum ferredoxin:NADP ${ }^{+}$oxidoreductase \\
\hline PfGR & P. falciparum glutathione reductase \\
\hline ROS & Reactive oxygen species \\
\hline TNT & 2,4,6-Trinitrotoluene \\
\hline TR & Trypanothione reductase \\
\hline
\end{tabular}

\section{References}

1. Bhatt, S.; Weiss, D.J.; Cameron, E.; Bisancia, D.; Mappin, B.; Dalrymple, U.; Battle, K.; Moyes, C.L.; Henry, A.; Eckhoff, P.A.; et al. The effect of malaria control on Plasmodium falciparum in Africa betwen 2000 and 2015. Nature 2015, 526, 207-211. [CrossRef] [PubMed]

2. Müller, S. Redox and antioxidant systems of the malaria parasite Plasmodium falciparum. Mol. Microbiol. 2004, 53, 1291-1305. [CrossRef] [PubMed]

3. Pelfrene, E.; Harvey Allchurch, M.; Ntamabyaliro, N.; Nambasa, A.; Ventura, F.V.; Nagercoil, N.; Cavaleri, M. The European Medicines Agency's scientific opinion on oral feximidazole for human African trypanosomiasis. PLoS Negl. Trop. Dis. 2019, 13, e0007381. [CrossRef]

4. Guissani, A.; Henry, Y.; Lougmani, N.; Hickel, B. Kinetic studies of four types of nitroheterocyclic radicals by pulse radiolysis. Correlation of pharmacological properties to decay rates. Free Radic. Biol. Med. 1990, 8, 173-189. [CrossRef] 
5. Wilkinson, S.R.; Bot, C.; Kelly, J.M.; Hall, B.S. Trypanocidal activity of nitroaromatic prodrugs: Current treatments and future perspectives. Curr. Top. Med. Chem. 2011, 11, 2072-2084. [CrossRef]

6. Pal, C.; Bandyopadhyay, H. Redox active antiparasitic drugs. Antiox. Redox Signal. 2012, 17, 555-582. [CrossRef]

7. Bironaitė, D.A.; Čènas, N.K.; Kulys, J.J. The rotenone-insensitive reduction of quinones and nitrocompounds by mitochondrial NADH-ubiquinone reductase. Biochim. Biophys. Acta 1991, 1060, 203-209. [CrossRef]

8. Čènas, N.; Nemeikaitè-Čènienè, A.; Sergedienè, E.; Nivinskas, H.; Anusevičius, Ž.; Šarlauskas, J. Quantitative structure-activity relationships in enzymatic single-electron reduction of nitroaromatic explosives: Implications for their cytotoxicity. Biochim. Biophys. Acta 2001, 1528, 31-38. [CrossRef]

9. Anusevičius, Ž.; Nivinskas, H.; Šarlauskas, J.; Sari, M.-A.; Boucher, J.-L.; Čènas, N. Single-electron reduction of quinone and nitroaromatic xenobiotics by recombinant rat neuronal nitric oxide synthase. Acta Biochim. Pol. 2013, 60, 217-222. [CrossRef]

10. Moussaoui, M.; Misevičienè, L.; Anusevičius, Ž.; Marozienè, A.; Lederer, F.; Baciou, L.; Čènas, N. Quinones and nitroaromatic compounds as subversive substrates of Staphylococcus aureus flavohemoglobin. Free Rad. Biol. Med. 2018, 123, 107-115. [CrossRef]

11. Henderson, G.B.; Ulrich, P.; Fairlamb, A.H.; Rosenberg, I.; Pereira, M.; Sela, I.; Cerami, A. "Subversive" substrates for the enzyme trypanothione disulfide reductase: Alternative approach to chemotherapy of Chagas disease. Proc. Natl. Acad. Sci. USA 1988, 85, 5374-5378. [CrossRef] [PubMed]

12. Č̀nas, N.; Bironaitè, D.; Dičkancaitè, E.; Anusevičius, Ž.; Šarlauskas, J.; Blanchard, J.S. Chinifur, a selective inhibitor and subversive substrate for Trypanosoma congolense trypanothione reductase. Biochem. Biophys. Res. Commun. 1994, 204, 224-229. [CrossRef] [PubMed]

13. Millet, R.; Maes, L.; Landry, V.; Sergheraert, C.; Davioud-Charvet, E. Antitrypanosomal activities and cytotoxicity of 5-nitro-2-furancarbohydrazides. Bioorg. Med. Chem. Lett. 2002, 12, 3601-3604. [CrossRef]

14. Arias, D.G.; Herrera, F.E.; Garay, A.S.; Rodrigues, D.; Forastieri, P.S.; Luna, L.E.; Bürgi, M.D.; Prieto, A.A.; Iglesias, A.A.; Cravero, R.M.; et al. Rational design of nitrofuran derivatives: Synthesis and valuation as inhibitors of Trypanosoma cruzi trypanothione reductase. Eur. J. Med. Chem. 2017, 125, 1089-1097. [CrossRef]

15. Leroux, A.E.; Krauth-Siegel, R.L. Thiol redox biology of trypanosomatids as potential targets for chemotherapy. Mol. Biochem. Parasitol. 2016, 206, 67-74. [CrossRef]

16. Ilari, A.; Genovese, I.; Fiorillo, F.; Battista, T.; De Iona, I.; Fiorello, A.; Colotti, G. Toward a drug against all kinetoplastids: From LeishBox to specific and potent trypanothione reductase inhibitors. Mol. Pharm. 2018, 15, 3069-3078. [CrossRef]

17. Kuntz, A.N.; Davioud-Charvet, E.; Dessolin, J.; Sayed, A.A.; Califf, L.L.; Arnér, E.S.J.; Williams, D.L. Thioredoxin glutathione reductase from Schistosoma mansoni: An essential parasite enzyme and a key drug target. PLoS Med. 2007, 4, e264.

18. Li, T.; Ziniel, P.D.; He, P.Q.; Kommer, V.P.; Crowther, G.J.; He, M.; Lin, Q.; Van Voorhis, W.C.; Williams, D.L.; Wang, M.W. High-throughput screening against thioredoxin glutathione reductase identifies novel inhibitors with potential therapeutic value for schistosomiasis. Infect. Dis. Poverty 2015, 4, 40. [CrossRef]

19. Grellier, P.; Šarlauskas, J.; Anusevičius, Ž.; Marozienė, A.; Houeee-Levin, C.; Schrevel, J.; Čènas, N. Antiplasmodial activity of nitroaromatic and quinoidal compounds: Redox potential vs inhibition of erythrocyte glutathione reductase. Arch. Biochem. Biophys. 2001, 393, 199-206. [CrossRef]

20. Wiesner, J.; Kettler, K.; Sakowski, J.; Ortmann, R.; Jomaa, H.; Schlitzer, M. Structure-activity relationships of novel anti-malarial agents: Part 5. N-(4-acylamino-3-benzoylphenyl)-[5-(4-nitrophenyl)-2-furyl]acrylic acid amides. Bioorg. Med. Chem. Lett. 2003, 13, 361-363. [CrossRef]

21. Tukulula, M.; Sharma, R.-K.; Meurillon, M.; Mahajan, A.; Naran, K.; Warner, D.; Huang, J.; Mekonnen, B.; Chibale, K. Synthesis and antiplasmodial and antimycobacterial evaluation of new nitroimidazole and nitroimidazooxazine derivatives. ACS Med. Chem. Lett. 2012, 4, 128-131. [CrossRef] [PubMed]

22. Munigunti, R.; Gathiaka, S.; Acevedo, O.; Sahu, R.; Tekwari, B.; Calderon, A.I. Characterization of PfTrxR inhibitors using antimalarial assays and in silico techniques. Chem. Cent. J. 2013, 7, 175. [CrossRef] [PubMed]

23. Burkard, L.; Scheuermann, A.; Simithy, J.; Calderon, A.I. Development of a functional assay to detect inhibitors of Plasmodium falciparum glutathione reductase utilizing liquid chromatography-mass spectrometry. Biomed. Chromatogr. 2015, 30, 543-547. [CrossRef] 
24. Vennerstrom, L.J.; Eaton, J.W. Oxidants, oxidant drugs, and malaria. J. Med. Chem. 1988, 31, $1269-1277$. [CrossRef]

25. Čènas, N.K.; Bironaitè, D.A.; Kulys, J.J.; Sukhova, N.M. Interaction of nitrofurans with glutathione reductase. Biochim. Biophys. Acta 1991, 1073, 195-199.

26. Cakmak, R.; Durdagi, S.; Ekinci, D.; Sentürk, M.; Topal, G. Design, synthesis and biological evaluation of novel nitroaromatic compounds as potent glutathione reductase inhibitors. Bioorg. Med. Chem. Lett. 2011, 21, 5398-5402. [CrossRef]

27. Sarma, G.N.; Savvides, S.N.; Becker, K.; Schirmer, M.; Schirmer, R.H.; Karplus, P.A. Glutathione reductase of the malarial parasite Plasmodium falciparum: Crystal structure and inhibitor development. J. Mol. Biol. 2003, 328, 893-907. [CrossRef]

28. Tyagi, C.; Bathke, J.; Goyal, S.; Fischer, M.; Dahse, H.M.; Chacko, S.; Becker, K.; Grover, A. Targeting the intersubunit cavity of Plasmodium falciparum glutathione reductase by a novel natural inhibitor: Computational and experimental evidence. Int. J. Biochem. Cell Biol. 2015, 61, 72-80. [CrossRef]

29. Böhme, C.C.; Arscott, D.; Becker, K.; Schirmer, R.H.; Williams, C.H., Jr. Kinetic characterization of glutathione reductase from the malarial parasite Plasmodium falciparum. Comparison with the human enzyme. J. Biol. Chem. 2000, 275, 37317-37323. [CrossRef]

30. Grellier, P.; Marozienè, A.; Nivinskas, H.; Šarlauskas, J.; Aliverti, A.; Čènas, N. Antiplasmodial activity of quinones: Roles of aziridinyl substituents and the inhibition of Plasmodium falciparum glutathione reductase. Arch. Biochem. Biophys. 2010, 494, 32-39. [CrossRef]

31. O'Brien, P.J.; Wong, W.C.; Silva, J.; Khan, S. Toxicity of nitrobenzene compounds towards isolated hepatocytes: Dependence on reduction potential. Xenobiotica 1990, 20, 945-955. [CrossRef]

32. Lukevits, E.; Demicheva, L. Biological activity of furan derivatives. Chem. Heterocycl. Comp. (Riga) 1993, 3 , 242-266.

33. Daghastanli, N.A.; Degterev, L.A.; Tedesco, A.C.; Borisevitch, I.E. Phototoxicity of a 5-nitrofuran-ethenylquinoline antiseptic (Quinifuryl) to P388 mouse leukemia cells. Braz. J. Med. Biol. Res. 2004, 37, 1873-1879. [CrossRef]

34. Tseng, C.H.; Tzeng, C.C.; Chiu, C.C.; Hsu, C.Y.; Chou, C.-K.; Chen, Y.L. Discovery of 2-[2-(5-nitrofuran-2-yl) vinyl]quinoline derivatives as a novel type of antimetastatic agents. Bioorg. Med. Chem. 2015, 23, 141-148. [CrossRef]

35. Wardman, P. Reduction potentials of one-electron couples involving free radicals in aqueous solution. J. Phys. Chem. Ref. Data 1989, 18, 1637-1755. [CrossRef]

36. Balconi, E.; Pennati, A.; Crobu, D.; Pandini, V.; Cerutti, R.; Zanetti, G.; Aliverti, A. The ferreroxin-NADP ${ }^{+}$ reductase/ferredoxin electron transfer system of Plasmodium falciparum. FEBS J. 2009, 276, 4249-4260. [CrossRef]

37. Seeber, F.; Aliverti, A.; Zanetti, G. The plant-type ferredoxin-NADP ${ }^{+}$reductase/ferredoxin redox system as a possible drug target against apicomplexan human parasites. Current Pharm. Des. 2005, 11, 3159-3172. [CrossRef]

38. Zhang, M.; Wang, C.; Otto, T.D.; Oberstaller, J.; Liao, X.; Adapa, S.R.; Udenze, K.; Bronner, I.F.; Casandra, D.; Mayho, M.; et al. Uncovering the essential genes of the human parasite Plasmodium falciparum by saturation mutagenesis. Science 2018, 360, eaap7847. [CrossRef]

39. Bironaite, D.A.; Chenas, N.K.; Kulis, Y.Y. Nonphysiological redox agents are reduced in the NADP(H) binding-site of glutathione reductase. Biochemistry-Moscow 1992, 57, 818-820. (in Russian).

40. Belorgey, D.; Lanfranchi, D.A.; Davioud-Charvet, E. 1,4-Naphthoquinones and other NADPH- dependent glutathione reductase-catalyzed redox cyclers as antimalarial agents. Curr. Pharm. Des. 2013, 10, 2512-2528. [CrossRef]

41. Salmon-Chemin, L.; Lemaire, A.; De Freitas, S.; Deprez, B.; Sergheraert, C.E.; Davioud-Charvet, E. Parallel synthesis of a library of 1,4-naphthoquinones and automatic screening of potential inhibitors of trypanothione reductase from Trypanosoma cruzi. Bioorg. Med. Chem. Lett. 2000, 10, 631-635. [CrossRef] 
42. Miškinienė, V.; Anusevičius, Ž.; Marozienè, A.; Kliukienè, R.; Nivinskas, H.; Šarlauskas, J.; Čènas, N.; Becker, K. Tetryl as inhibitor and subversive substrate for human erythrocyte glutathione reductase. In Proceedings of the 13th International Symposium on Flavins and Flavoproteins, Konstanz, Germany, 31 August-4 September 1999; Ghisla, S., Kroneck, P., Macheroux, P., Sund, H., Eds.; Rudolph Weber: Berlin, Germany, 1999; pp. 703-706.

43. Foley, M.; Tilley, L. Quinoline antimalarials: Mechanisms of action and resistance and prospects for new agents. Pharmacol. Ther. 1998, 79, 55-87. [CrossRef]

44. Famin, O.; Krugliak, M.; Ginsburg, H. Kinetics of inhibition of glutathione-mediated degradation of protoporphyrin IX by antimalarial drugs. Biochem. Pharmacol. 1999, 58, 59-68. [CrossRef]

45. Marva, E.; Chevion, M.; Golenser, J. The effects of free radicals induced by paraquat and copper on the in vitro development of Plasmodium falciparum. Free Rad. Res. Comun. 1991, 12, 137-146. [CrossRef] [PubMed]

46. Chaudhari, R.; Sharma, S.; Patankar, S. Glutathione and thioredoxin systems of the malaria parasite Plasmodium falciparum: Partners in crime? Biochem. Biophys. Res. Commun. 2017, 488, 95-100. [CrossRef] [PubMed]

47. Ayi, K.; Cappadoro, M.; Branca, M.; Turrini, F.; Arese, P. Plasmodium falciparum glutathione metabolism and growth are independent of glutathione system of host erythrocyte. FEBS Lett. 1998, 424, 257-261. [CrossRef]

48. González-Párraga, P.; Hernández, A.; Argüelles, J.C. Role of antioxidant enzymatic defences against oxidative stress, $\mathrm{H}_{2} \mathrm{O}_{2}$, and the acquisition of oxidative tolerance in Candida albicans. Yeast 2003, 20, 1161-1169. [CrossRef]

49. Dixit, V.; Pandey, V.; Shyam, R. Differential antioxidative responses to cadmium in roots and leaves of pea (Pisum sativum L. cv. Azad). J. Exp. Bot. 2001, 52, 1101-1109. [CrossRef]

50. Pedrosa, R.C.; De Bem, A.F.; Locatelli, C.; Pedrosa, R.C.; Geremias, R.; Wilhelm Filho, D. Time-dependent oxidative stress caused by benznidazole. Redox Rep. 2001, 6, 265-270. [CrossRef]

51. Č̀nas, N.; Prast, S.; Nivinskas, H.; Šarlauskas, J.; Arner, E.S.J. Interaction of nitroaromatic compounds with the mammalian selenoprotein thioredoxin reductase and the relation to induction of apoptosis in human cancer cells. J. Biol. Chem. 2006, 281, 5593-5603. [CrossRef]

52. Monti, D.; Basilico, N.; Parapini, S.; Pasini, E.; Olliaro, P.; Taramelli, D. Does chloroquine really act through oxidative stress? FEBS Lett. 2002, 522, 3-5. [CrossRef]

53. Becker, K.; Tilley, L.; Vennerstrom, J.L.; Roberts, D.; Rogerson, S.; Ginsburg, H. Oxidative stress in malaria parasite-infected erythrocytes: Host-parasite interactions. Int. J. Parasitol. 2004, 34, 163-189. [CrossRef] [PubMed]

54. Morin, C.; Besset, T.; Moutet, J.-C.; Fayolle, M.; Brückner, M.; Limosin, D.; Becker, K.; Davioud-Charvet, E. The aza-analogues of 1,4-naphthoquinones are potent substrates and inhibitors of plasmodial thioredoxin and glutathione reductases and of human erythrocyte glutathione reductase. Org. Biomol. Chem. 2008, 6, 2731-2742. [CrossRef]

55. Dong, C.K.; Patel, V.; Yang, J.C.; Dvorin, J.D.; Duraisingh, M.T.; Clardy, J.; Wirth, D.F. Type II NADH dehydrogenase of the respiratory chain of Plasmodium falciparum and its inhibitors. Bioorg. Med. Chem. Lett. 2009, 19, 972-975. [CrossRef]

56. Č̀nas, N.K.; Arscott, D.; Williams, C.H., Jr.; Blanchard, J.S. Mechanism of reduction of quinones by Trypanosoma congolense trypanothione reductase. Biochemistry 1994, 33, 2509-2515. [CrossRef]

57. Kröger, M.; Fels, G. ${ }^{14}$ C-TNT synthesis revisited. J. Label. Compd. Radiopharm. 2000, 43, 217-227. [CrossRef]

58. Hughes, E.D.; Ingold, C.; Pearson, R.B. Nitration at nitrogen and oxygen centers. Part I. Kinetics and conversion of secondary amines into nitroamines. J. Chem. Soc. 1958, 4357-4365. [CrossRef]

59. Khan, A.H.; Ross, W.C.J. Tumor-growth inhibitory nitrophenylaziridines and related compounds: Structure-activity relationships. Chem. Biol. Interact. 1969, 1, 27-47. [CrossRef]

60. Sukhova, N.M.; Lidaka, M.J.; Voronova, V.A.; Zidermane, A.A.; Kravchenko, I.M.; Dauvarte, A.Z.; Preisa, I.E.; Meirena, I.E. Substituted 2-[2'-(5"'-nitrofuryl-2")vinyl- and 4'-(5"-nitrofuryl-2")-1,3- butadienyl)-quinoline4-carboxylic acid amides and salts thereof. U.S. Patent 4201784A, 6 May 1980.

61. Lukevits, E.; Lapina, T.V.; Sukhova, N.M.; Zidermane, A.A.; Dauvarte, A.Z.; Voronova, V.A. Nitrogencontaining organosilicon compounds. CIV. Synthesis and antiblastic activity of amides of quinoline carboxylic acids. Pharm. Chem. J. 1981, 15, 792-794. [CrossRef] 
62. Trager, W.; Jensen, J.B. Human malaria parasites in continuous culture. Science 1976, 193, 673-677. [CrossRef]

63. Desjardins, R.E.; Canfield, C.J.; Haynes, J.D.; Chullay, J.D. Quantitative assessment of antimalarial activity in vitro by semiautomated microdilution technique. Antimicrob. Agents Chemother. 1979, 16, 710-718. [CrossRef]

Sample Availability: Samples of the compounds 3,15-22 (Table 1) are available from the authors.

(C) 2019 by the authors. Licensee MDPI, Basel, Switzerland. This article is an open access article distributed under the terms and conditions of the Creative Commons Attribution (CC BY) license (http://creativecommons.org/licenses/by/4.0/). 